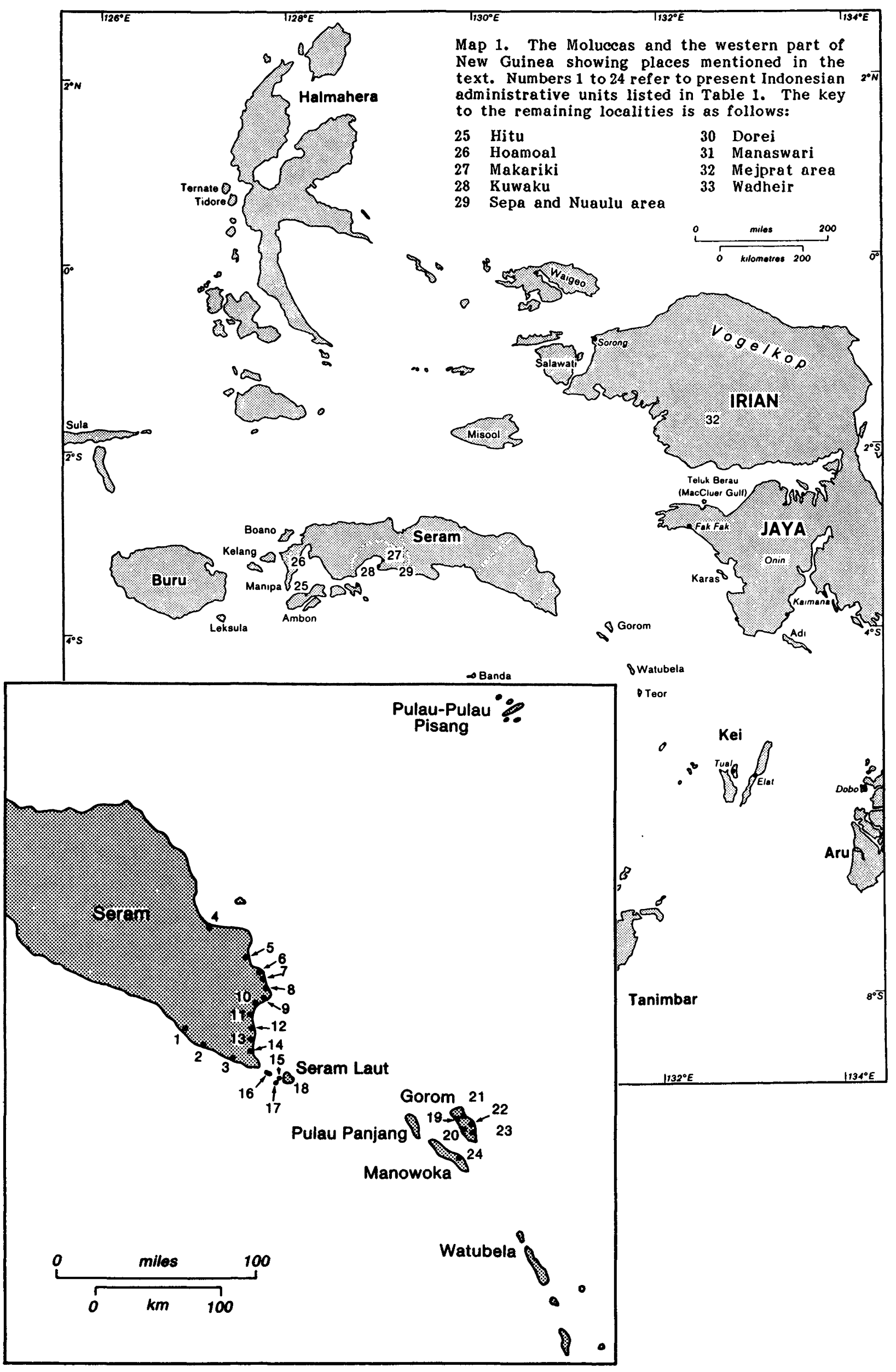




\title{
CONUNDRUMS ABOUT PANJANDRUMS: ON THE USE OF TITLES IN THE RELATIONS OF POLITICAL SUBORDINATION IN THE MOLUCCAS AND ALONG THE PAPUAN COAST 1
}

\author{
R. F. Ellen \\ Titles are shadows, crowns are empty things. 2
}

Introduction

\begin{abstract}
Anyone who has even a passing acquaintance with the ethnographic and historical literature on the Malay world will know of that frustratingly unhelpful term orang kaya. In the written form it is variously rendered "orang kaja," "orang kâja," "orangquai," "orangcaij," "orangcay," "orangkaij," or "orang caija." A Malay word, usually translated literally as "rich or influential person," 3 it appears in the Portuguese sources and then fairly continuously in the Dutch and British archives and published literature. The problem is that throughout the historical and geographic range of its use the term is employed for figures in many apparently different fields, ranging through the nobility, rich merchants, elders, and appointed colonial officials. It is, therefore, not surprising that it has
\end{abstract}

1. The data on which this paper is largely based were assembled during three months' tenure at the Netherlands Institute for Advanced Study (NIAS) at Wassenaar. I would like to thank the director and his staff for providing me with some scholarly breathing space in otherwise pinched times. I am indebted to Gerrit Knaap for his comments on an earlier version, to Barry Hooker for putting me in touch with some comparative material from the Malay peninsula, and to John Villiers and Leonard Andaya for some clarification of the Portuguese materials. For the most part, I have adopted a consistent spelling for titles found in the historical sources. For European loan words, I have followed the usage of C. D. Grijns, J. W. de Vries, and L. Santa Maria, European Loan Words in Indonesian (Leiden: KITLV for Indonesian Etymological Project, 1983). In some cases this may violate the precise pronunciation of local variants (e.g., kapitein = kapitan).

2. Daniel Defoe, The True-born Englishman (London: Routledge, 1910), pt. 2, p. 206, line 313.

3. A. L. N. Kramer Sr. in his Kamus Indonesia (The Hague, Jakarta: van Goor, 1951), p. 137, gives "rijke," "voorname." John M. Echols and Hassan Shadily, in An Indonesian-English Dictionary, 2nd ed. (Ithaca: Cornell University Press, 1963), p. 261, with more circumspection, opt for "important person." Milner reminds us that "kaya" may be glossed as "power," "wealth," or "property," with etymological priority being given to "power": A. C. Milner, Kerajaan: Malay Political Culture on the Eve of Colonial Rule, Association for Asian Studies Monogr. 40 (Tueson: University of Arizona Press, 1982), p. 25. 
been confusing as much as elucidating, for scholars every bit as much as for traders, administrators, and natives. In this article I confine myself to the Moluccan islands of eastern Indonesia, and within this area propose to concentrate on the settlements of archipelagic and mainland southeast Seram, and on that extreme western part of New Guinea (Irian Jaya) which is of ten described in early documents as "the Papuan coast" (see map 1). In this way I may at least shed some light on the puzzle of the transference of titles of the orang kaya kind, as it is apparent in one part of the region.

Sixteenth and Seventeenth Century Usages: On the Description and Misunderstanding of Unf amiliar Political Cultures

When Europeans first arrived in the eastern archipelago, local rulers were often described to them by their hosts, interpreters, and guides as raja (raje, radja) and orang kaya. These terms were, to begin with, translated directly into Western tongues to facilitate the production of written reports. In the early Portuguese documents, for example, the generic term "king" (rei, el rey, rayall [real]) 4 was used for various kinds of political leader. However, local terms were fairly quick to appear, perhaps because the authors soon realized that no easy equation could be established between Western and Oriental titles, or because they did not wish to press a similarity which might have political or moral implications. António Galvão, who visited the Moluccas around 1544, lists a number of local titles and attempts to draw parallels with European ranks. Thus, the king of Ternate is described as kolono, and "dukes" as sengaji, both authentic Ternatan terms. However, he also speaks of "knights" (marsaoli) and "gentlemen" (menterie) and uses "raja" for queen. 5 In the Portuguese accounts, native chiefs who were not called raja are called "regedor." Unlike the terms kapitan (kapitao), "captain" or "commander in chief," and mayor (which we shall meet later), this was not a term which was ever introduced into the local political vocabulary, at least not for any length of time. The term "orang kaya" rarely appears in the Portuguese documents, but it is common from the beginning in those of the Dutch East India Company. For example, the Corpus Diplomaticum for the early years of Dutch contact contains many communications of the following kind:

Van Van Speult, 23 Dec. 1624 orang kaya Sobo, wegers die of Ceram laoet, en orang kaja Simon Bal, uit den naam, en van wegen die . . . (and so on). 6

Similarly, Haga 7 refers to the contract drawn up by Van Speult on December 23, 1624 which lists all the rulers (or at least the persons of influence) for Seram

4. See e.g., A Treatise on the Moluccas, Probably the Preliminary Version of António Galvåo's Lost 'Historia das Molucas,' ed. Hubert Th. Th. M. Jacobs S.J. (Rome: Jesuit Historical Institute, 1974), pp. 90, 93, 103.

5. "A primeyra e primeipal dynydade éa rayall a que chamăo culano, he a rainha rajas, os duques samguajens, hos cavaleyros marcoles, e fidalguos mamdarins, . . . (Galvăo [c. 1544], lines 9-11 of Capitolo Dezaoyto, in Jacobs, ed., Treatise on the Moluccas, p. 102).

6. Corpus Diplomaticum Neerlandico-Indicum, vol. 1, ed. J. E. Heeres and F. W. Stapel (The Hague, for Koninklijk Instituut voor Taal-, Land- en Volkenkunde, 1907), p. 201.

7. A. Haga, Nederlandsch Nieuw Guinea en Papoesche Eilanden: Historische bijdrage, $\pm 1500-1883,2$ vols. (Batavia: Bruining, The Hague: Nijhoff, 1884), 1: 45. 
Laut, Heralieu, Keffing, Goram, Guli-guli, Urang, Coac [Kuwaku], as "orang kaya." In a document of 1637 the "Hoofd regent" of Seram Laut is referred to as "orang kaya Baud." 8 Keijts, writing somewhat later, in 16789 uses orang kaya generally to refer to men of influence or middlemen (of Moluccan origin) living and controlling trade on the Onin peninsula of western New Guinea. He also speaks of the "orang kaya" of Keffing. 10 Rumphius uses "orang kaya" throughout his De generale Landbeschrijving 11 to describe various political leaders in the Seram Laut archipelago, and appears to use the Dutchified plural "orangcaijen" to refer to all influential personages. There are many similar references in the archives and early printed sources, and it would serve no useful purpose to list more than a handful here.

The term "orang kaya" was additionally applied to the very different political leadership of the Banda islands, with its "oligarchy of elders." Here, each village had an achieved leader whose power at the time of Portuguese contact appeared to derive from his monopoly of the export of spices. However, the Portuguese sources are of limited help. For Hanna, 12 writing from Dutch records, it was "a term which signified leading citizens and therefore chiefs," who met frequently in village councils to deal with problems and settle disputes. We have no evidence of an indigenous Bandanese term for this position. In some circles "orang kaya," though not a native Bandanese term, has become attached to a distinctive kind of authority in these "republican" village communities, one which seems almost implicitly modeled on the late medieval Italian republics. Because authority appears to have been derived from wealth, Villiers 13 has described this as a "mercantile aristocracy," an inference which I believe to be profoundly misleading. For Banda before 1621 we also find the title syahbandar, "harbor master."14 Individuals referred to in this way were probably foreigners who had a role regulating relations in the trading community, and of ten they were appointed for particular ethnic trading groups by local rulers, as in Java. 15

In Ambon at the beginning of the seventeenth century the "orang kaya" acted as agents, advancing cloth to the local inhabitants against a certain percentage. This commission increased yearly if the producer failed to turn in his clove

8. Reinier de Klerk, Belangrijk verslag over den staat van Banda en omliggende eilanden aan zijne excellentie de Gouverneur-Generaal . . . met eene korte beschrijving van Banda ... door C. A. M. van Vliet (The Hague: van Stockum, 1894 [first published in 1756]).

9. Haga, Nederlandsch Nieuw Guinea, 1: 106.

10. Ibid., p. 109.

11. Georg Eberhard Rumpf (Rumphius), De generale Land-beschrijving van het Ambonsche Governement, Algemeen Rijksarchief, The Hague (hereafter ARA), VOC 11247, e.g., p. 85.

12. W. Hanna, Indonesian Banda: Colonialism and its Aftermath in the Nutmeg Islands (Philadelphia: Institute for the Study of Human Issues, 1978), pp. 14, 23-24.

13. John Villiers, "Trade and Society in the Banda Islands in the Sixteenth Century," Modern Asian Studies 15, 4 (1981): 728-29.

14. Hanna, Indonesian Banda, pp. 14, 24.

15. E.g., Peter Carey, "Changing Javanese Perceptions of the Chinese Communities in Central Java, 1755-1825," Indonesia 37 (April 1984): 6. 
harvest satisfactorily until he eventually became a debt slave. According to Gijsels, 18 to whom we owe this information, only two "orang kaya" at this time were truly Ambonese--one came from Seram--while others were of mixed JavaneseAmbonese parentage. Such "orang kaya" were feted, almost worshipped.

On Ambon at this time the term "orang kaya" appears to have been used to refer to middlemen, who could be spoken of in no other way, and also to traditional rulers. Other, local, terms were also in use. For example, at the end of the fifteenth century in Hitu, on what is now Ambon island, patriclans were headed by upu and groupings of upu (uli) were headed by a primus-inter-pares called tamata-ela or tamaela, and groups of a greater degree of inclusiveness by amanopunyo. Interestingly (though not surprisingly, perhaps), there were Malay equivalents for the titles at these various levels: kepala negeri (upu), kepala uli and the empat perdana level (plus, raja Hitu, orang kaya Bulang, and Orang kaya Ternate). At all three levels (though mainly at the top) there were individuals who claimed foreign descent, but the lines must have been very mixed. 17

Thus, the term "orang kaya" is used variously to refer to indigenous ascribed leaders (chiefs), traditional leaders of the "big man" variety who had attained authority by the manipulation of resources in indigenously approved ways, local persons who acquired influence by virtue of being middlemen in the commodity trade, and foreign merchants. We cannot assume, however, that any of these categories were always mutually exclusive. Tiele, 18 quoting from a seventeenth century Dutch source, indicates that the term was beginning to be used generically from the earliest period of contact:

Deselve Keffingers hebben ons ter plaetse voonoemt grote dienst gedaen, die oock eenige Orangquais van hare cleene negorij hebben doen compareren ende belooft alle trouwe aen $t$ fort te bewijsen.

By the mid-seventeenth century it was being used routinely in Dutch, and indeed in German, 19 as a generic term for men of influence. It is hardly an exaggeration to say that the Dutch thus appropriated the term and applied it more widely to any indigenous person of power, or persons they wished to empower, in their management of political affairs. But it is also evident that some Malay titles were already part of local parlance before the arrival of Europeans. 20

Both "raja" and "orang kaya" are words of Malay origin. Their widespread use was partly because in trade Malay was the main medium of discourse. There

16. Gijsels, "Grondigh Verhael van Amboyna ..." Kroniek van het Historisch Genootschap te Utrecht 27 (1871): 350-58.

17. Z. J. Manusama, "Hikayat Tanah Hitu: Historie en Sociale Structuur van Ambonse Eilanden in het Algemeen en Uli Hitu het Bijzonder tot het Midden de Zeventiende Eeuw" (Ph.D. thesis, Leiden University, 1977); Gerrit Knaap, personal communication.

18. Bouwst offen voor de Geschiedenis der Nederlanders in den Maleischen Archipel, ed. P. A. Tiele, 2 vols. (The Hague: Nijhoff, 1890), 2: 244.

19. J. S. Wurffbain, Reise nach den Molukken 1. 1632-1646 (The Hague: Nijhoff, 1931 [1680]), vol. 1. Wurffbain (p. 90) speaks of the "Orang kayas of besagtem Ceram Laut," and the "Orang kayas von Keffing."

20. Paramita R. Abdurachman, "New Winds, New Faces, New Forces," Paper presented at the Conference on "Southeast Asian Responses to European Intrusions," British Institute in Southeast Asia, Singapore, 1981. 
is proof that Moluccans used Malay in their dealings with the outside world from as early as 1514, the date of Portuguese translations of two Malay letters from the King of Ternate found in Malacca.21 However, it is reasonable to suppose that spoken Malay had been a trade language for some centuries before them.

Why these particular Malay titles were used can be explained in part by looking at usages in the homeland of the Malays. The title "orang kaya" is still found in the traditional Malay states of the peninsula and east Sumatra, and, tellingly, the dictionary definition of Harahap 22 is "orang berada, pegawai tinggi dalam keradjaan." Windstedt and Wilkinson 23 indicate that the term was of ten a component of longer titles, such as "orang kaya mantri Sri Paduka Tuan." In Perak, after the sultan and other high officials of state, the first level of four great chiefs are known collectively as "orang kaya," the next level of eight chiefs (the "orang besar delapan") are also styled, Acehnese fashion, "orang kaya kaya." 24 The term "orang kaya besar" appears to have been used generically, and Barbara Andaya, 25 in her work on eighteenth century Perak uses "orang besar" and "orang kaya" interchangeably for district heads. Although, in this case, it appears that the system of titles was considerably elaborated in the nineteenth century by the British in an attempt to embellish with pomp and frumpery the courts of indirect rule, it is pretty clear that the term "orang kaya" was an ascribed title, though its semantic range was fairly broad. Nevertheless, once a language becomes a lingua franca employed by many for whom it is not a first language, terms can take on special intersubjective meanings, indeed new words and syntactical structures may emerge which bear little relation to social, cultural, and linguistic forces in the homeland. There is reason to believe that this must early have been the case for "orang kaya" in the eastern archipelago. 26

Eighteenth and Nineteenth Century Usages: The Creation and Manipulation of Authority Structures

From the time they first arrived in the Moluccas, Europeans began to bestow titles on people they thought to be local dignitaries, first as a gesture of respect following the canons of European courtly diplomacy, and latterly as a means of

21. A. A. Cense, "Malaise Invloeden in het Oostelijk Deel van de Indonesische Archipel," Bijdragen tot de "Taal-, Land- en Volkenkunde [hereafter BKI] 134, 4 (1978): 418.

22. E. St. Harahap, Kamus Indonesia (Bandung: Kolff, 1951), p. 24.

23. R. O. Winstedt and R. J. Wilkinson, "A History of Perak," Journal of the Malayan Branch of the Royal Asiatic Society 12, 1 (1934): 143.

24. Ibid., pp. 137, 143, 145.

25. Barbara Watson Andaya, Perak, the Abode of Grace: A Study of an Eighteenth Century Malay State (Kuala Lumpur: Oxford University Press, 1979), pp. 28, 413.

26. In this connection see O. W. Wolters, History, Culture and Region in Southeast Asian Perspectives (Singapore: Institute of Southeast Asian Studies, 1982), pp. 52-69. This is a useful discussion of what Professor Wolters describes as the process of "localisation," of how imported ideas, terms, and objects are "fractured and restated and ... drained of their original significance" (p. 52) through their necessary construal in terms of the modes of cognition, representation, and expression of the host culture. I am indebted to Anthony Milner for drawing my attention to this reference. 
political control. Local individuals had to be found to take responsibility, and Europeans assumed local leadership and status systems to resemble their own. They chose persons who appeared to have authority (though they scarcely examined the basis of such authority), or persons who had done them a service (though omitting the possibility that this involved a reciprocal disservice). Understandably, the local situation was of ten grossly distorted. When Serrăo arrived in Hitu in January 1512 he was cordially received by the empat perdana (council of four) in return for bestowing (erroneously) the title of kapitan and the honorific dom on the spokesman of the council, taking him for the local ruler. 27 Later, when the polity of Hitu was centralized, the new ruler became known as the "kapitan Hitu," the first local ruler to adopt this European title.

By the late nineteenth century there was a confusing array of titles derived from local, Malay, and European sources, which had been enshrined in the political system by Dutch use. The administrative rank of a titleholder was additionally reflected in regalia and clothing of European origin. Bik28 reports that the orang kaya of Ainike on Manawoka had a stick with a gold knob given to him by the English government. The orang kaya of Wadheir in the Aru islands is described by $\mathrm{Bik} 29$ as wearing red breeches, a satin shirt, and a long tail coat, augmented by a light blue dress coat with enameled buttons and silver lace. Rewards were also made for singular services. Abdul Mahiet, the orang kaya of Ondor at the time of Bik's visit 30 was given a gold medal by the English Resident Martin in return for his assistance against Prince Ibrahim of Tidore.

In the Dutch colonial system of titles the term "orang kaya" ranked alongside other titles of European, Malay, and local origin and became a title which could be conferred upon particular individuals, rather than just a general term of reference or address. "Kapitan," for example, had been introduced from the Portuguese, and "mayor" from the Dutch. Riedel 31 says that "mayor" and "kapitan" are both of Portuguese origin, but we need not quibble. Holleman 32 additionally lists gezaghebber (a temporary appointment to manage interregna, a "dorpschoofd ad interim, totdat de nog onmodige titularis benoemd kan worden") known to him from the negori of Kilwaru. In this context "orang kaya" was absorbed into local political systems, as an autocthonous title, along with "kapitan," from the Portuguese. We know that by the first half of the nineteenth century some of the polities of archipelagic southeast Seram were ruled by independent orang kaya, and that other nucleated polities had both raja, and beneath them an orang kaya, and even other titles (e.g., Kelu, Ondor). Other polities were dispersed, ruled by raja but with orang kaya heading particular villages. Thus, the orang

27. Paramita R. Abdurachman, "Moluccan Responses to the First Intrusions of the West," in Dynamics of Indonesian History, ed. H. Soebadio and C. A. du Marchie Sarvaas (Amsterdam: North-Holland, 1978), p. 170.

28. A. J. Bik, Dagverhael Eener Reis, Gedaan in het Jaar 1824 tot Nadere Verkenning der Eilanden Kefing, Goram, Groot-Klein Kei en de Aroe-eilanden (Leiden: Sijthoff, 1928 [1824]), p. 19.

29. Ibid., p. 50 .

30. Ibid., p. 22.

31. J. G. F. Riedel, De Sluik- en Kroesharige Rassen tusschen Selebes en Papua (The Hague: Nijhoff, 1886), p. 154.

32. "Jurisprudentie van de Inheemsche Rechtspraak op Boeroe, Ceram, Aroe en Tanimbar," ed. F. D. Holleman, Adatrechtbundels 24 (1925): 145. 
Table 1. Aecognized titles used by the Dutch administration for some listed domeins (gabjed) in southeast Seram between 1855 and 1928. In all ceses 8pelling has been modified to accord with current orthography.*

\begin{tabular}{|c|c|c|c|}
\hline $\begin{array}{r}\text { Present } \\
\text { units } \\
\text { (brackets if }\end{array}$ & $\begin{array}{l}\text { Indonesian administrative } \\
\text { (Peaerintah negeri) } \\
\text { indicate contemporary groupings) }\end{array}$ & $\begin{array}{l}\text { Nineteenth century title } \\
\text { (brackets indicote nineteenth } \\
\text { century groupings] }\end{array}$ & $\begin{array}{l}\text { Mineteenth } \\
\text { century } \\
\text { domain }\end{array}$ \\
\hline A. & $\begin{array}{l}\text { SOUTH COAST OF SERAM } \\
\text { 1. Tobo } \\
\text { 2. Kilmuri } \\
\text { 3. Urung }\end{array}$ & $\begin{array}{l}\text { raja } \\
\text { raja } \\
\text { forang kaya } \\
\text { lorang kaya }\end{array}$ & $\begin{array}{l}\text { Tobo } \\
\text { Kilmuri } \\
\text { Urung } \\
\text { Gulf Gult }\end{array}$ \\
\hline B. & $\begin{array}{l}\text { EAST COAST OF SERAM } \\
\text { 4. Waru } \\
\text { 5. Gah } \\
\text { 6. Warus Warus } \\
\text { 7. Air Kasar } \\
\text { 8. Sesar } \\
\text { 9. Kilbat } \\
\text { 10. Kilmoi PN } \\
\text { 19. Denama } \\
\text { 12. Kiandarat } \\
\text { 13. Kianlaut } \\
\text { 14. Kwaos }\end{array}$ & $\begin{array}{l}\text { orang kaya } \\
\text { orang kaya } \\
\text { orang kaya } \\
\text { orang kaya } \\
\text { orang kaya } \\
\text { orang kaya } \\
\text { kapitan } \\
\text { aengaji } \\
\text { raja }\end{array}$ & $\begin{array}{l}\text { Waru } \\
\text { Gah } \\
\text { Warus Warus } \\
\text { Kilbet } \\
\text { Kilmoi } \\
\text { Danama } \\
\text { Kianderat } \\
\text { KianLaut } \\
\text { Kwaos }\end{array}$ \\
\hline c. & KEFFING & & \\
\hline & $\begin{array}{l}\text { 15. Kelu } \\
\text { 18. Keffing }\end{array}$ & $\begin{array}{l}\text { rajo } \\
\text { lorang kayat } \\
\text { mayor }\end{array}$ & $\begin{array}{l}\text { Kelu } \\
\text { Kwai } \\
\text { Keffing }\end{array}$ \\
\hline $\begin{array}{l}\text { D. } \\
\text { E. }\end{array}$ & $\begin{array}{l}\text { GESER } \\
\text { 17. BeBer } \\
\text { SERAM LAUT }\end{array}$ & mayor: & \\
\hline F. & $\begin{array}{l}\text { 18. Talang } \\
\text { KILWARU }\end{array}$ & $\begin{array}{l}\text { raja } \\
\text { kapitans }\end{array}$ & $\begin{array}{l}\text { Kilwaru } \\
\text { Kiltai }\end{array}$ \\
\hline 6. & $\begin{array}{l}\text { EOROM } \\
\text { 19. Kataloka } \\
\text { 20. Ondor } \\
\text { 21. Mide } \\
\text { 22. Det }\end{array}$ & $\begin{array}{l}\text { raja } \\
\text { rajah } \\
\text { orang kaya } \\
\text { orang kaya }\end{array}$ & $\begin{array}{l}\text { Kataloka } \\
\text { Ondor } \\
\text { Mida } \\
\text { Dai }\end{array}$ \\
\hline & 23. Rarat & $\begin{array}{l}\text { orang kaya } \\
\text { orang kaya } \\
\text { orang kaya } \\
\text { mayor }\end{array}$ & $\begin{array}{l}\text { Kalaikat } \\
\text { Surukat } \\
\text { Nama Len } \\
\text { Kiliwou }\end{array}$ \\
\hline H. & MANOWOKA & & \\
\hline I. & $\begin{array}{l}\text { 24. Amar } \\
\text { PULAU PANJANG }\end{array}$ & $\begin{array}{l}\text { raja } \\
\text { orang kaya } \\
\text { orang kaya }\end{array}$ & $\begin{array}{l}\text { Amar } \\
\text { Ainikke } \\
\text { Besilem Nia }\end{array}$ \\
\hline
\end{tabular}

- Based on the following sources: C. Bosscher, "Bijdrage tot de Kennis van het Dostelijke Gedeelte van Ceram en oml iggende El landen," Tiddachrift voor Indische Tael-, Lend- en Volkenkunde 4 (1855): 34, 39-39; P. van der Crab, De MoLuksche Ej lenden: Reis ven Z. E. Den Gouverneur Generael C. P. Pahud (Batavia: Lange, 1862), pp. 180-89; J. B. J. van Doren, Frageanten Uit de Relzen in den Herinner Ingen en Schetsen ven lederlende Oost Indies Vervale on de Frensenten Ujt Raizen in dí Gejesten (Ams terdan:

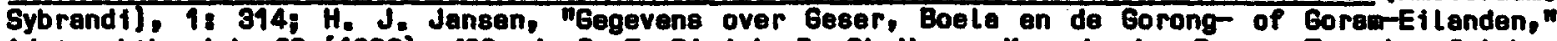
Adatrechtbundels 36 [1928]: 490; J. B. F. Riedel, De Sluik- en Kroesharige Rassen Tusgchen Selebes en Papug (The Haguea MiJhoff, 1883), P. 154 ; and ARA KOL 1881 mailrapport 6412-6781.

t Bik reports Kelu as having both orang kaye and kepiten; A. J. Bik, Dagverheal Eener Beis, Bedagn in het Jaar 1824 tot Madare Verkenning der EjLanden Kefing, Goras, Groot-KLein Kei en de Aroe-Eilenden [Leiden: Sij thoff, 1928 [1824]], P. 9; 880 also ARA KOL (1814-49), 6381: 49-71.

* Bik, Degyerheel. PP. 22-24, uses the term "oreng kaye," though possibly in the generic sense.

\$ See also ARA KOL $[1814-49), 6381: 49-71$.

9 Bik, Dagverhael, P. 29, reports "orang kayas." From the context it is likely thet the term may heve been used in a generic sense, and that the recognized super-ordinate was rala. 
kaya of Ainike (with a population as high as 1,100), and Besilan, on Pulau Panjang, were under the raja of Amar, while the orang kaya of Kwai was under the raja of $\mathrm{Kelu}$, and the kapitan of Kiltai, under the raja of Kilwaru. The situation as it had been consolidated in archipelagic southeast Seram between 1855 and 1928 is shown in table 1.

Of the Malay titles, "orang kaya" and "raja" are the most common. Among titles of local origin incorporated into the structure of colonial administration was patih (a term of Javanese or Sanskritic origin, found, for example, in the south Seramese village of Makariki) and, in one place, sengaji. 33 In Kilwaru in 198134 informants well remembered the three titles of the Dutch period, which (in increasing rank) were patih, orang kaya, and raja. All were addressed locally as Jou (Jou patih, jou orang kaya, jou raja). 35 The titles were initially in the gift of the Dutch government and then inherited, while from time to time persons could be upgraded from lower to higher rank. It is recalled that Resident De Hagen established a number of titles in this area seventy-eight years ago. The raja of Gorom Kataloka is constantly addressed as "jou" and jou is a title used for any of the raja's family. 36

Jensen 37 talks of "orang kaya" as a term for "village head" in his ethnography of west Seram, and this term was well implanted in the early nineteenth century, judging from reports. In some cases this was tied directly to the conferring of new titles on existing personages by the intrusive powers, and local respect for such titles. In other cases it was the result of directly imposed ranking systems (as in Ambon-Lease). Elsewhere (and more generally) it was simply that the increasing use of Ambonese Malay (with large numbers of European loan words) led to the gradual use of exogenous in preference to local terms. As a purely linguistic phenomenon, this kind of lexical substitution is well documented. Thus Collins 38 suggests that the widespread occurrence of words such as kakatua in contemporary central Moluccan languages can only be explained by the prominence of their referents as trade items, perhaps combined with the fact that the original names were concealed (in the case of "kakatua," because this is widely held as a

33. P. van der Crab, De Moluksche Eilanden: Reis van Z. E. Den Gouverneur Generaal C. P. Pahud (Batavia: Lange, 1862), p. 62.

34. R. F. Ellen, Fieldnotes, 1981-4-5.

35. This is a term of apparently Ternatan origin, and in different parts of the Moluccas is used in slightly different ways. "Bapak jou" was the title commonly used by the raja and people of Sepa for the government-appointed village head (kepala pemerintah) of the Nuaulu village of Ruhuwa, otherwise called kepala soa. There is a mention of the cognate title "kapalla-joa" on p. 10 of Reglement op het Binnenlandsch Bestuur en dat de Financien op Amboina en Onderhoorigheden, Ambon 15th April 1824, ARA, Min. van Kolonien (hereafter ARA KOL) 2766 (2.10.01). The title is common in the Ambon area.

36. R. F. Ellen, Fieldnotes, 1981-3-53.

37. A. E. Jensen, Die Drei Strome: Zuge aus dem Geistigen und Religiosen Leben der Wemale, einen Primitieve-Volk in den Molukken, Ergebnisse der FrobeniusExpedition, 1937-38 in die Molukken und nach Hollandisch Neu-Guinea, vol. 2 (Leipzig: Harrassowitz, 1948), p. 46.

38. J. Collins, "The Historical Relationship of the Languages of Central Maluku, Indonesia" (Ph.D. dissertation, University of Chicago, 1980), p. 168. 
sacred bird and totem). In this he is in agreement with Chlenov, 39 who has argued that many terms important for trading tend to be borrowed from consumers of the product, becoming incorporated into the language, and of ten coinciding with words for "gold" and "wealth." Unlikely as it may seem on the face of it, this hypothesis works well with "orang kaya." Indigenous titles in eastern Indonesia are sometimes concealed, and "kaya" certainly indicates wealth. Such externally derived (and later imposed) titles stuck because they were necessarily in constant use in a complex emergent polylinguistic and polycultural society, consisting of large numbers of small independent or quasi-independent polities.

This kind of lexical absorption has occasionally taken the form of appropriation of colonial and other titles and their incorporation into personal names. Thus, Hille $\mathbf{4 0}$ speaks of the political head of Kaimana on the coast of New Guinea as "raja Komisi," thus using two terms neither of which is indigenous to the area. Komisi was presumably a proper name, taken from the Dutch "commisaris," as in the similar Nuaulu case. 41 Kamma 42 records instances where "mayor" and "dimara" were used as family names in the western Vogelkop. 43

There are four general points that we should remember when trying to comprehend the colonial use of titles in the Moluccas. Firstly, the various "gebied" were divided into kampong, 44 many of which had a titled head. In van der Crab's list of 186245 these are generally described as "orang tua," though occasionally different kampong within the same "gebied" may have heads with different recognized titles. By 1881 "the rajas, pattis, orang kayas and orang tuas. are all kampong heads." 46 Thus, in the "gebied" of Kilmuri, the kampong of Dawang, Afang, and Kamar have orang tua, although Batoloming has a mayor. In Kilwaru, Geser has a mayor, Kiltai a kapitan, and Maar an orang tua. The appearance of the same titles at both kampong and "gebied" level suggests that in certain cases places or individuals may change status over time; alternatively the Dutch may have found it politic to grant titles in this way. Secondly, titles appear to have nothing to do with the size of the population. Thus, Keffing, with a population of 785 in 1855, had a mayor while Kelu (with only 630 inhabitants) boasted a raja. Thirdly, in some

39. M. A. Chlenov, "Cultural Vocabulary as an Indicator of Inter-ethnic Relations: Eastern Indonesian Evidence," BKI 134, 4 (1980): 437.

40. J. W. van Hille, "Reizen in West-Nieuw-Guinea," Tijdschrift van het Koninklijk Nederlandsch Aardrijkskundig Genootschap 22 (1905): 293.

41. R. F. Ellen, "Semantic Anarchy and Ordered Social Practice in Nuaulu Personal Naming," BKI 139 (1983): 31.

42. F. C. Kamma, "De Verhouding tussen Tidore en de Papoese Eilanden in Legende en Historie, II," Indonesil 1 (1948): 182.

43. J.-E. Elmberg, Balance and Circulation: Aspects of Tradition and Change among the Mejprat of Irian Barat (Stockholm: Ethnographical Museum Monograph, Series No. 12, 1968), p. 80.

44. C. Bosscher in his "Bijdrage tot de Kennis van het Oostelijke Gedeelte van Ceram en Omliggende Eilanden," Tijdschrift voor Indische Taal-, Land- en Volkenkunde 4 (1855): 38, talks of "distrikten" and negorijn, and by 1925 gebied were known as regentschap and all heads were regents. See "Jurisprudentie van de Inheemsche Rechtspraak," ed. Holleman, p. 134.

45. Van der Crab, De Moluksche Eilanden, pp. 60-61.

46. ARA KOL 1881 mailrapport 6412791. 
cases the title is due to depletion of higher titles (temporary or permanent) when traditional polities split or were dismembered. Thus, in 1824, Keluara (Kilwaru) had both a raja and a kapitan. 47 Fourthly, there was great inequality in the size of the units recognized and used for the purpose of that peculiarly loose form of indirect rule where polities were, for all intents and purposes, independent until the second half of the nineteenth century.48 By 192849 there were raja in Kwaos, Kilwaru, Kelu, Amar, Kataloka, Ondor, Kilmuri, Tobo, and Hatumeten, a mayor on Keffing, but autonomous orang kaya in Denama, Kilmoi, Kilbat, and Urang. Part of the reason for this was political expediency, part resulted from historical accident, but also because few details were available on the jurisdiction of persons given titles. Ignorance of this kind was common well into the nineteenth century. 50

It is necessary to mention ascription and achievement here as a basis for the award of titles, although there are regrettably no consistent usages. For Riedel, 51 orang kaya were chosen, raja were hereditary. Similarly, in the southeast Seram area, at the present time, there are two types of raja: raja turunan (e.g., Kataloka, Kilmuri, and Amsakeru) and raja angkat where the raja is selected from the orang kaya on the basis of their various reputations (e.g., Ondor). However, it is clear that raja angkat are a relatively recent introduction, while orang kaya are by no means always achieved positions. On Gorom at the present time, "orang kaya" is used to refer to the sons of a raja. 52

Another kind of title either introduced by the Dutch or modeled on an existing function was that of chiefs appointed from local ethnic minorities. This device was particularly used in important trading centers. Thus, there was a kapitan cina in Ambon in 1824.53 Carey has recently provided an excellent description of the role of the kapitan cina in eighteenth and nineteenth century Java, though such usages are also known from the seventeenth century and earlier. 54 Thus, the Dutch appointed a kapitan of Chinese in Japara, 55 and instituted a kapitan Peranakan in eighteenth century Java.56 Carey quotes Ong Tae-hae:

47. Bik, Dagverhael, p. 5 .

48. G. J. Resink, "Independent Rulers, Realms, and Lands in Indonesia, 18501910," in Indonesia's History between the Myths: Essays in Legal History and Historical Theory (The Hague: van Hoeve, 1968).

49. H. J. Jansen, "Gegevens over Geser, Boela en de Gorong- of Goram-eilanden," Adatrechtbundels 36 (1928): 490.

50. Van der Crab, De Moluksche Eilanden, p. 62.

51. Riedel, De Sluik- en Kroesharige Rassen, p. 155.

52. R. F. Ellen, Fieldnotes, 1981-3-49.

53. Bik, Dagverhael, p. 8.

54. L. Blusse, "Batavia, 1619-1740: The Rise and Fall of a Colonial Town," Journal of Southeast Asian Studies 12, 1 (1981): 167, 170-71; see also M. A. P. MeilinkRoelofsz, Asian Trade and European Influence in the Indonesian Archipelago between 1500 and about 1630 (The Hague: Nijhoff, 1962).

55. Carey, "Changing Javanese Perceptions," p. 10.

56. Ibid., p. 7 . 
The flowery Chinese and every description of foreigners have all got Captains placed over them, who are charged with the regulation of affairs belonging to their own countrymen. . . .57

Ong also described the ceremony for the appointment of a kapitan commenting that it was in this way that the Dutch got "our people into their net." According to Carey: 58 "The later years of Amangkurat II's reign saw attempts to control the increasing numbers of Chinese in the Mataram dominions by the appointment of local Chinese officers (kapitan cina, litnan cina, etc.) who were subordinate to the Chinese syahbandar of Japara (post-1708, Semarang) and who had the task of managing the affairs of larger settlements on the north coast," although of ten these appointments were ineffective when it came to policing disputes.

In the Moluccas we know that the first kapitan cina in Kota Ambon was appointed in about 1625.59 Holleman 80 speaks of the "wijkmeester de Chineezen" on Kelu. Where intrusive ethnic groups had no leader of their own, one was created; for example, on Banda the Chinese had both a kapitan and a luitenant, 81 and there was a kapitan of the Bandanese Arab community (1850-1899), 62 It is possible that in some of these cases such quasi-military titles were applied to functions previously performed by the syahbandar. 63

Titles and Political Expansion in Indigenous Moluccan Society: The New Guinea Case

The ubiquitousness of the "orang kaya" usage (and its cognates) should not be seen in isolation. It is a specific example of a general phenomenon, particularly well exemplified in the eastern Malay world, of the relationship between titles and power. This is especially so at that point where the Malay world meets New Guinea.

In the first half of the sixteenth century there were four Muslim rulers in the Moluccas: Ternate, Tidore, Bacan, and Jailolo. Of these only Ternate used the title "sultan"; the rest used "raja." The districts or provinces of Ternate and the other domains were headed by persons described as "sengaji," who were sometimes

57. Ibid., p. 10, quoting Ong Tae-hae, The Chinaman Abroad: or a Desultory Account of the Malayan Archipelago, Particularly of Java, edited and translated by W. H. Medhurst (Shanghae: Mission Press, 1849), pp. 4, 8-9, 20.

58. Carey, "Changing Javanese Perceptions, p. 10.

59. Gerrit Knaap (personal communication) suggests that his name was Herman because he had been christened during the office of Governor Herman van Speult. See G. E. Rumphius, "De Ambonsche Historie . . . , BKI 64 (1910), I, p. 54.

60. "Jurisprudentie van de Inheemsche Rechtspraak," ed. Holleman, p. 137.

61. J. B. J. van Doren, Herinneringen de Laatste Oogenblikken van mijn Verbliff in de Molukko's (The Hague: Van Langenhuysen, 1852), p. 16.

62. Hanna, Indonesian Banda, p. 125.

63. Gerrit Knaap writes (personal communication, "In Kota Ambon, the second appointed kapitan cina, Artus Gijsels (circa 1635-1675) acted as a syahbandar for the city. However, he was the first and last one to do so, since from circa 1675 onwards the VOC instructed its fiscaal (a European) to take over this business." 
also known as "raja" or "patih." 84 From around 1495 Ternate extended its political influence to the Hoamoal peninsula of Seram, to Buru, Manipa, Kelang, and Boano. This area of influence also included Ambon, where there developed a system of political organization containing the distinctive elements of Ternatan political culture: the soa or latu, a permanent chief rather than a rotating primus inter pares. 85 Kimelaha, which in Ternatan means "village headman," represented the Sultan and resided in a specially created settlement on the Hoamoal peninsula.88 As far as the VOC was concerned, they were merely "stadthouders." Abdurachman 67 is of the opinion that there was also a Ternatan kimelaha on Banda, but the evidence for this is slight. Indeed, during the first half of the seventeenth century, kimelaha Leliato of Ternate claimed the whole south coast of Seram as far as (and including) Keffing. 68 The new settlements appear to have been ruled by local leaders granted the title of sengaji, who in some ways were functionally comparable to regents. Under the new dispensation their subordinates were kipati, village headmen.

The title "sengaji" was introduced to east Seram not by Ternate, but by Tidore, which claimed suzereignty over the area.68 of more significance for the present discussion, however, is the fact that Tidore bestowed titles on Melanesians from Biak and elsewhere as a kind of acknowledgement for the payment of tribute. This was exacted primarily from peoples on the Papuan coast, who were to degrees subject to Tidoran influence, and whose leaders brought their tribute to Tidore with the east monsoon. The titled persons so created were, as part of their duties, required to collect further tribute. Biak, for example, is believed to have been incorporated into this kind of structure by the end of the fifteenth century.

Tidoran titles bestowed on Melanesians appear originally to have referred to real political functions, as understood by the Tidorans themselves. Thus, "raja" (head of an independent political domain), "sengaji" (district chief), "dimara," and "korano" (kimelaha $=$ village headman) 70 were conferred according to the Tidorese division of the Biak regions into districts. The functionary received from the sultan a flag and a sort of official dress, after the manner of the installation of Moluccan orang kaya by Europeans. Later on clothes were given and titles were conferred quite arbitrarily, without reference to the intended or actual function of the bearer.71 The way in which the son of a titled person received his title after his father's death shows that there was no longer any real function: he was simply asked to choose from a series enumerated by one of the village elders. 72

64. Jacobs, Treatise on the Moluccas, pp. 3, 5 .

65. Manusama, "Hikayat Tanah Hitu."

66. R. Z. Leirissa, "Notes on Central Maluku in the 19th Century," Prisma, September 22, 1981, pp. 54-55.

67. Abdurachman, "Moluccan Responses," p. 172.

68. Haga, Nederlandsch Nieuw Guinea, 1: 43.

69. Van der Crab, De Moluksche Eilanden, p. 62.

70. Kamma, "De Verhouding," pp. 181, 540.

71. Elmberg, Balance and Circulation, p. 128.

72. F. C. Kamma, Koreri: Messianic Movements in the Biak-Numf or Culture Area, Koninklijk Instituut voor Taal-, Land- en Volkenkunde, Translation Series No. 15 (The Hague: Nijhoff, 1972), p. 9. Translation of De Messiaanse Koreri-bewegingen in het Biaks-Noemfoorse Cultuurgebied (Den Haag, Krt. Proefschrift, Leiden, 1954). 
Robide van de $A A 73$ reports that the head of Dorei, on the northern coast of the Vogelkop, had been given the title of "korano," and that lesser heads had such titles as "mayor" and "kimelaha." The title of "korano" appeared to descend through the patrilineal line (through a son, brother, or brother's son). Tidorese and Biak political culture, it would seem, had insufficient in common for the Biak to employ titles in ways resembling those used by the Tidorese themselves. Nevertheless, as with the Tidorese, titles were treated as incorporeal property which, like various forms of esoteric knowledge and personal names, constituted part of the status of the individual and his descendents. Titles derived from Tidore did not give any political power; nor did they give authority in the internal affairs of the group. Although the representatives of this remote sultanate, who annually collected tribute on the coasts of western New Guinea, made active attempts to establish a permanent authority, they never really succeeded.74 Indeed, in the perceptions of the Melanesians, the relationship with Tidore was hardly seen as one of subjugation. If anything, they saw it in opposite terms. Indeed, "those who took tribute to Tidore and returned with a title, a flag, and ceremonial dress, celebrated the acquisition of these attributes of dependence with the same ceremony that was performed on returning from a successful headhunting expedition."75 Moreover, raids of Biak pirates in the Moluccas caused almost as much fear as Tidorese hongi raids in the other direction. 78

The southwestern coast of New Guinea was on the fringe of Tidorese influence, but had long been in contact with traders from archipelagic southeast Seram, who themselves were under the influence of Tidore. The Serammers had established what they described as sosolot, stretches of coast in which particular individuals (orang kaya) and villages had exclusive trading rights. In these sosolot, for example along the southern edge of Teluk Berau (the McCluer Gulf), were found by the nineteenth century (when the Dutch first embarked upon effective administration) middlemen or "chiefs" with such Indonesian titles as "raja," "orang kaya," "mayor," and "kapitan"; and special Moluccan titles like "jojau," "sengaji," and "korano." The occurrence of these titles is partly bound up with the tribute "exacted" by Ternate and Tidore, 77 as described above. The local use of such titles, however, goes back much further than the nineteenth century. As early as 1653 there are references to orang kaya, and even to the "kings" of Onin, the peninsula immediately south of Teluk Berau.78 By 1702 we also find the titles of "kapitan" and "raja" mentioned. There are additionally documentary reports of Keffingese orang kaya on the New Guinea coast between 1680 and 1684.79 We now know, as Keijts--who first reported these persons-did not, that there was no trace of political domination by Serammers, Seramlauters, and Goramese, at least as we would normally understand it. This was the case despite the fact that

73. P. Robide van de AA, Reizen naar Nieuw Guinea Ondernamen op Last der Regeering van Ned. Indie in de Jaren $1871,72,75,76$ door van der Crab, J. $E$. Teysmann, J. G. Coorengel en A. J. Langeveldt van Hemert en $P$. Swaan (The Hague: Nijhoff, 1879), p. 73.

74. Elmberg, Balance and Circulation, p. 203.

75. Ibid., p. 74.

76. Ibid., p. 216.

77. Ibid., p. 127.

78. See also Hille, "Reizen in West-Nieuw-Guinea," p. 25.

79. Haga, Nederlandsch Nieuw Guinea, 2: 68, 70. 
the Onin coast was populated by Seramese (even with some intermarriage), was evidently partly Islamicized, and used Seramese pidgin as a lingua franca. 80

It has long been observed that so-called "chiefs" were created quite easily along the coast of New Guinea. Indeed, Forrest, writing in 1775 from Dorei, 81 explains nonchalantly how on Manaswari island he made a man "a Capitano, by giving him a frock and draws of chintz, and firing off three guns, this being the Dutch ceremony." Apparently, "he [the man] returned to Dory very well pleased, and very vain of his dress." Goudswaard 82 noted that the insignificance of such titles, and the authority connected with them, was well demonstrated by the fact that traders and even missionaries appointed subchiefs. Such "chiefs" were essentially agents used by traders to represent their interests once they had left for home; persons who would see to it that upon their return goods were ready. 83 Goudswaard informs us, in the same passage referred to, that "they take a mambri, a brave or rich man of some influence, give him a pair of trousers, a jacket and a headcloth, give him three blows on the head while simultaneously crying out 'majoor' or 'kapitein laut'; after the title is proclaimed this person crys out 'ho.' They then fire a shotgun in his honour and by this he is established as a chief. The wife of a celebrated trader (Mrs. Fabritius) has raised some three or four persons to majoor or kapitein laut who had proved themselves very serviceable as her agents." 84 Dissel 85 found the claims of "mock chiefs" ridiculous, and founded on the ancient idea that any foreign strand dweller would think himself the lord and master of every living thing in the interior. For the Melanesians, the lack of respect for such titles is indicated by the use of nicknames for "chiefs" appointed over them, such as "raja gatel" ("the king of itch"), or "kapitan sandu" ("captain of opium").86 These accounts might profitably be compared with more recent writings on the appointment, role, and status of village government officials in Papua New Guinea. 87

What is of further interest is that the Biakers on the northern coast of the Vogelkop peninsula themselves conferred titles on their traditional trading and exchange partner (or manibob), apparently modeled on their experience of the

80. Hille, "Reizen in West-Nieuw-Guinea," pp. 253-54.

81. T. Forrest, A Voyage to New Guinea and the Moluccas, 1774-1776, edited with an introduction by D. K. Bassett (Kuala Lumpur: Oxford University Press, $1969[1780])$, p. 110.

82. A. Goudswaard, De Papoew's van de Geelvinksbaai (Schiedam, 1863), p. 60.

83. Adatrechtbundels, Gemengd (The Hague: Nijhoff, 1930): 33, 388.

84. Trans. Elmberg, Balance and Circulation, p. 129, n. 35. A. C. Kruijt, in his "De To Loinang van den Oostarm van Celebes," BKI 86 (1930): 358, tells how in the Celebes the sultan of Ternate used to create dakanjo leaders who brought in the yearly tribute, through a similar process of dressing and firing a shot. Referred to in Elmberg, Balance and Circulation, p. 129.

85. J. S. A. van Dissel, "Reis van Goras langs de Bedidi naar Ginaroe," Tijdschrift van het Koninklijk Nederlandsch Aardrijkskundig Genootschap 24 (1907): 1023.

86. J. S. A. van Dissel, "Landreis van Fakfa naar Sekor," Tijdschrift van het Koninklijk Nederlandsch Aardrijkskundig Genootschap 21 (1904): 790; "Reis van Goras," pp. 992-94, 1002.

87. Charles Rowley, The New Guinea Villager: The Impact of Colonial Rule on Primitive Society and Economy (London: Pall Mall Press, 1966), pp. 84-86. 
Tidorese custom. These manibob maintained contact with the inland population and were often themselves in turn appointed agents with different titles by the sultan of Tidore. 88 Subclans were headed by government officials given Malay titles; some of these were even regarded as chiefs of the larger patriclans (fam). That titles introduced as part of the process of political subordination should be hijacked by the indigenous population and used in ways other than those intended is known in other parts of Indonesia. 89

Our data for all this come from the last part of the nineteenth century. Under the contemporary post-colonial Indonesian administration the old pattern reemerges once again. For example, Elmberg 90 reports how Malay notions of rank and authority have filtered into and affected the activities of exchange cycles among the Mejprats, where "big men" seek to expand their activities and to strengthen connections by comparing themselves with coastal agents, such as the mayor of Konda. Among the Malay titles confirmed in the Indonesian administrative structure are "kepala kampong," and for lower chiefs, "raja," "mayor," "kapitan," and, of course, the ubiquitous "orang kaya." Interestingly, however, a counterreport by $A$. C. van de Leeden 91 indicates a recent tendency in the Raja Ampat Islands to replace old sultanate titles by traditional clan names.

\section{Conclusion}

The Dutch and Indonesian use of titles in New Guinea was in many respects like that of their predecessors. This suggests that we might be able to generalize even more widely about the use of titles in situations where relations of subjugation are being created and maintained, or perceived to be so in the eyes of the selfstyled superordinates.

Firstly, in the various cases of political subordination described here, the dominators share a notion of "title" which is linked to a concept of ascribed authority. The specific notion may, in fact, vary: from strict Dutch notions of representative authority, to notions linked to a Malay- or Javanese-type conception of power. When such titles were distributed among political clients by potentates in the Moluccas, superordinates and subordinates shared many of the same assumptions about power, and other elements in their political culture. In New Guinea no respect was shown for such ranks and titles, partly because such persons lacked effective power (e.g., control of the means of production, circulation, or destruction) and partly because in New Guinea power is not thought of as a disembodied quality. In contrast, Melanesian power is recognized only in its

88. Elmberg, Balance and Circulation, pp. 128, 203; after Dissel, "Landreis van Fakfa," p. 790; "Reis van Goras," pp. 992-94, 1002.

89. James Fox, in his Harvest of the Palm: Ecological Change in Eastern Indonesia (Cambridge, Mass. and London: Harvard University Press, 1977), p. 84, tells us that when the term "raja" was introduced to Roti for titled rulers in the various domains, the Dutch could not contain it as a sign of rule, in the sense required, and the term spread throughout the entire island as a general sobriquet.

90. Elmberg, Balance and Circulation, p. 20.

91. A. C. van der Leeden, "Report on Anthropological Fieldwork at the Northern Raja Ampat Islands, March-June 1979," in Halmahera dan Raja Ampat: Konsep dan Strategi Penelitian, ed. E. K. M. Masinambow (Jakarta: LEKNAS-LIPI, 1980), p. 212. 
concrete manifestations, e.g., in the control of pigs, women, mastery of warfare, words, and the means of production. Imported titles seem to have been recognized in the Moluccas for what they were intended to be, in a way which was not the case in New Guinea. 92 The reasons appear to be the long prior period of historical contact with the Javanese, a cognitive and political culture more receptive to notions of hierarchy and inequality, and to power as a concrete, homogeneous, and constant quantity, rather than something abstract, heterogeneous, limitless, and morally ambiguous, the product of achievement.93 To put it in terms which Sahlins might have employed, the contrast is between "the prince of Danes" as opposed to "the prince among men." 94

Secondly, it would seem that titles always move from the intrusive (though not always materially stronger) polity to the intruded upon.95 Thus they appear as a particular and very obvious example of what others have seen fit to call the law of cultural dominance, 96 part of the apparatus for instituting new power relations between ethnic groups; at the same time power in themselves and the legitimation of relations of power. The provision of such a cultural infrastructure is a necessary condition for the development of relations of subordination, but it is hardly sufficient, and probably not determinant either. To it must be added objective subordination which can be measured only in material terms. On the other hand, if from the first instance of culture contact material subordination is effective, we may reasonably assume that the re-jigging of cultural definitions of power and authority and the role of titles cannot lag far behind. In fact, it may concentrate the "callective consciousness" on the adjustment of ruling representations in a critical way. However, the New Guinea case (although it is possible that the situation in the Raja Ampat Islands was different) provides an example of how the presence of abstract titles may be separated from the rest of the apparatus and be reconstituted in terms of the existing relations of power management. Thus recontextualized, they can be adopted by peoples who in every other respect may politically resist the encroachments of the dominant culture on their political sovereignty. They may also be adopted independent of, or even contrary to, the intentions of those from whom they were adopted. So, in the very process of defending their political autonomy against the domination of outside powers their culture is (paradoxically) transformed, more closely approaching that which is incipiently "dominant."

92. Elmberg, Balance and Circulation, p. 131.

93. Benedict R. O'G. Anderson, "The Idea of Power in Javanese Culture," in Culture and Politics in Indonesia, ed. Claire Holt et al. (Ithaca and London: Cornell University Press, 1972), pp. 5-8.

94. Marshall D. Sahlins, "Poor Man, Rich Man, Big-man, Chief: Political Types in Melanesia and Polynesia," Comparative Studies in Society and History 5 (1962-63): $289,294$.

95. Where there is a lingua franca from which they are drawn, it is true that they may also be acquired laterally.

96. [David Kaplan], "The Law of Cultural Dominance," in Evolution and Culture, ed. M. D. Sahlins and E. R. Service (Ann Arbor: The University of Michigan Press, 1960), p. 88 . 